\title{
ПУЛЬС КРИЗИСОВ
}

\author{
Н. Ю. СИлАЕВ
}

\section{Помощь НАТО Украине после Майдана*}

\author{
Николай Юрьевич Силаев, канд. ист. наук, ст. науч. сотр. \\ Центра проблем Кавказа и региональной безопасности \\ Института международных исследований МГИМО МИД России. \\ E-mail: nikolai.silaev@gmail.com
}

\begin{abstract}
Аннотация. Отношения Украины и НАТО в течение многих лет были одной из центральных проблем дискуссии о европейской безопасности. Государственный переворот и гражданская война на Украине созда^и новую ситуацию в отношениях Киева с альянсом. Обе стороны получили сильный импульс к сотрудничеству. При этом вместо прежних препятствий к их сближению возник^и новые. Анализ помоши, которую оказывают Украине НАТО и его к^ючевые члены после фревра^я 2014 г., позволяет судить о характере их отношений в новой ситуации и мотивах, которыми руководствуются государства альянса, выбирая те или иные варианты помоши. Несмотря на широкую политическую подлержку, оказываемую Украине, они слержаны в практической помоши. Поставки оружия невелики по объему. Основной формой помоши стало более интенсивное участие военнослужаших Украины в международных учениях НАТО и присутствие воинских контингентов блока (прежле всего, США) на территории Украины. Хотя США и НАТО стремятся подтвердить и отчасти усилить свои неформальные обязательства в отношении Украины, они также стараются избегать Аействий, которые могли бы поставить их на грань прямого столкновения с Россией. Таким образом, отношения НАТО и Украины могут служить типичным примером «Аилеммы союза».
\end{abstract}

КАючевые слова: Украина, НАТО, международная помошь, военное сотрудничество, российско-украинские отношения, союз.

В многолетней дискуссии о европейской системе безопасности одним из важнейших предметов была и остается Украина [3]. Исторически обеспечивая России стратегическую глубину обороны в европейских конфликтах, она перестала играть эту роль после распада СССР. Будучи крупнейшей после России страной постсоветского пространства, Украина с 2004 г. непосред-

*Исследование выполнено при финансовой поддержке Российского фонда фундаментальных исследований в рамках проекта № 17-03-12024 «Информационно-аналитическая система “Индекс Евразии”» В МГИМО МИД России. 
ственно граничит с НАТО. Для восточноевропейских членов альянса, прежде всего Польши, такое соседство сделало особенно драматическим вопрос о будущем Украины. Ее присоединение в той или иной форме к российской системе безопасности означало бы, что новые члены НАТО оказывались на линии соприкосновения военных машин альянса и России. Это стало одним из факторов их заинтересованности в дальнейшем расширении блока; им хотелось перенести некомфортную границу дальше на восток. Расширение НАТО, которое в условиях сдержанной реакции России стало расцениваться на Западе как процесс почти автоматический (или по крайней мере не требующий напряженных раздумий и подробных объяснений), в прошлом десятилетии захватило в свою орбиту Украину: на саммите в Бухаресте в апреле 2008 г. ей было обещано членство в альянсе; в украинской политике проявили себя влиятельные силы, заинтересованные в таком исходе. Это вызвало резкую реакцию со стороны Москвы [2, с. 81].

Положение осложнялось тем, что лавирование украинского политического руководства между Россией и Западом не сопровождалось выстраиванием сколько-нибудь устойчивого внутриполитического консенсуса и не имело определенных долгосрочных целей. Украина оставалась страной, расколотой в отношении языка, исторической памяти, желательных внешнеполитических ориентиров, религии. Колебания официального Киева не смягчали расколы, а усиливали их - вплоть до открытого вооруженного гражданского противостояния, начавшегося в 2014 г.

При обсуждении истоков текущего украинского кризиса тема НАТО занимает одно из центральных мест. Так, Дж. Миршаймер описывает украинский кризис - рубежное для отношений России и Запада явление - в категориях баланса сил, говоря о приближении сферы влияния Запада к границам России, заставляющем ее беспокоиться о собственной безопасности. Он подчеркивает многомерный характер этого «наступления»: расширение НАТО, экспансия ЕС и предложенной им институциональной рамки, политика продвижения демократии, проводимая США и их союзниками, в результате которой к власти в постсоветских странах приходили политики, враждебные России [7, с. 29]. Миршаймер полагает, что украинский кризис стал следствием недооценки западными политиками и дипломатами реалистических подходов во внешнеполитическом планировании; по его мнению, если рассуждать в реалистической логике, кризис был совершенно предсказуем [6, с. 1], причем «действия Путина были оборонительными, а не наступательными» [6, с. 9]. Он идет дальше, отождествляя разногласия между Россией и Западом с разногласиями между реалистическим (Россия) и либеральным (Запад) пониманием природы международных отношений [6, с. 8]. Важная часть аргументации Миршаймера - предположение, что расширение НАТО, экспансия Европейского союза и западная политика продвижения демократии составляли единое целое и в этом качестве вынуждали Москву к ответным действиям [7, с. 29].

М. Макфол, полемизируя с Дж. Миршаймером, утверждает, что российская внешняя политика изменилась не под влиянием экспансии Запада, а в силу внутриполитических причин. В бытность президентом Д. А. Медведева Россия сотрудничала с США, в том числе воздержавшись при голосовании в Совете Безопасности ООН по вопросу о Ливии. Макфол подчеркивает, что при Медведеве тема расширения НАТО не присутствовала в российско-американской переговорной повестке [5, с. 169]. Однако В. В. Путин стал использовать противостояние с США в целях укрепления собственной легитимности, и это привело к его ошибочным решениям в ходе украинского кризиса. При этом он реагировал, по мнению Макфола, не на расширение НАТО само по себе, а на особую интерпретацию событий, вынуждающую его видеть нарушение баланса сил и ситуативно реагировать на это [5, с. 170].

Более нюансированный подход представлен в работе Т. Колтона и С. Чарапа: политика «модульного» расширения западных институтов в Восточной Европе предполагала, что институты не могут быть изменены, а меняться должны только те, кто претендует на членство в этих институтах; такой подход оставлял Россию за рамками возможного участия в предлагаемых Западом структурах. Политические сигналы, которые подавала Россия первоначально, оказались слишком слабыми, чтобы политики в Вашингтоне и других западных столицах прислушивались к ее озабоченностям. Когда же эти сигналы стали действительно сильными, логика односторонних действий и игры с нулевой суммой оказалась слишком укоренившейся, чтобы ее можно было поменять [2, с. 45, 158-159].

Хотя кризис 2014 г. подвел черту под прежней историей Украины, отношений России и Запада, соперничества между Россией и НАТО, он не снял с повестки дня саму тему. Властям Украины удалось консолидировать поддержку идеи членства в НАТО. До кризиса эта идея не 
пользовалась поддержкой большинства, сейчас она стала более популярной. В своем военном строительстве официальный Киев ориентируется на НАТО как на образец и на вероятного партнера, стремясь приблизиться к стандартам НАТО и обеспечить оперативную совместимость с войсками альянса [1, с. 35]. Многообразные экономические связи России и Украины с начала кризиса сокращаются, в том числе в результате сознательной политики властей двух стран [4]. Тем не менее препятствие к членству Украины в НАТО состоит в продолжающемся конфликте на ее территории и в споре с Россией о принадлежности Крыма.

Если до 2008 г. политика расширения НАТО воспринималась на Западе как успех, не требующий жертв и усилий, то после 2008 г., а особенно после 2014 г. цена продолжения такой политики на постсоветском пространстве резко возросла. Однако отказываться от нее в условиях острой конфронтации с Россией в западных столицах было сочтено неприемлемым, поскольку могло быть истолковано как принятие условий Москвы. Был начат поиск решений, которые, не увеличивая объема обязательств со стороны НАТО его партнерам на постсоветском пространстве, в то же время позволяли укреплять сотрудничество с ними, поддерживая неформальные союзнические отношения.

Хотя для государств, заключающих союзы, может иметь значение именно формальная, юридически обязывающая основа союзнических отношений, в определенных условиях они могут предпочесть неформальный порядок сотрудничества. В ряде работ обсуждается вопрос о взаимозаменяемости различных видов союзнических или квазисоюзнических отношений. Так, Керен Яри-Мило, Александр Ланошка, Зак Купер на материалах из истории отношений США с Израилем и Тайванем в президентства Ричарда Никсона, Джеральда Форда, Джимми Картера исследуют стратегическую логику, которая может стоять за решениями о поставках оружия государству-клиенту. Они отмечают, что поставки оружия и союзнические обязательства могут дополнять друг друга или быть отчасти взаимозаменяемыми, и, поставляя оружие клиенту, государство-патрон сигнализирует о своих намерениях содействовать его безопасности. Они также высказывают предположение, что некоторые иные виды сотрудничества, например совместные военные учения, размещение военных баз, могут использоваться в качестве дополнения или замены союзнических обязательств или поставок вооружений. Именно так авторы расценивают американскую военную помощь Украине - как замену ее членства в НАТО. В то же время отмечают они, об уровне неформальных обязательств и гарантий может сигнализировать масштаб военной помощи [9, с. 91-92, 95, 137, 139].

Анализ военной помощи, которая оказывается Украине по линии НАТО и ключевых государств - членов и партнеров альянса, поможет определить, чем являются современные отношения Киева с блоком. Можно ли говорить о неформальном союзе? Насколько глубокие изменения претерпело сотрудничество НАТО с Украиной после 2014 г.? Насколько велики неформальные обязательства НАТО перед Украиной? Кто несет на себе основное бремя помощи Украине? Что можно сказать о мотивах США и других членов НАТО, если судить по характеру и объему помощи?

\section{Новых институтов не потребовалось}

Сотрудничество Украины с НАТО распадается на два потока: взаимодействие Киева с собственно альянсом и помощь, которая оказывается по линии отдельных государств НАТО или партнеров альянса. При этом структуры самого НАТО сравнительно пассивны в том, что касается практического содействия Украине. Основной объем помощи направляется по двусторонним каналам.

Существует официальное объяснение, согласно которому союзные структуры НАТО не располагают ресурсами, необходимыми для оказания масштабной помощи Украине. Однако блок в сравнительно небольшой степени использует и свои возможности по координации действий членов альянса, оказывающих содействие Киеву. Вероятно, это является следствием, с одной стороны, бюрократического характера союзных структур НАТО, а с другой - сохраняющихся внутри альянса разногласий по поводу его курса в отношении Украины. Сохраняются противоречия между США, с одной стороны, и Германией, и Францией, с другой стороны, по поводу перспектив членства Украины в альянсе. Некоторые соседи Украины используют свое членство в альянсе для продвижения собственных интересов в отношении Украины. Так Венгрия бло- 
кирует встречи комиссии НАТО - Украина', добиваясь от Киева изменения его языковой политики (НАТО публично не признает, что комиссия не созывается в связи с позицией Венгрии). Нельзя исключить, что схожую практику может заимствовать и Польша, учитывая ее портящиеся отношения с Киевом. Это усложняет оказание Украине содействия со стороны НАТО, так как институты альянса становятся инструментом оказания давления на Киев со стороны его соседей, пусть даже поддерживающих членство в нем Украины.

Ключевые механизмы сотрудничества Украины и НАТО были созданы еще до 2014 г. K настоящему времени отношения между Киевом и Брюсселем набрали инерцию, и Украина идет к тому, чтобы стать одним из ближайших партнеров блока, не будучи его членом. При этом НАТО создает общую институциональную рамку для взаимодействия Украины и Запада в сфере обороны и безопасности, но перспективы непосредственного военного сотрудничества между Украиной и Западом связаны не столько с взаимодействием Киева с Брюсселем, сколько с двусторонними связями с США и их ближайшими союзниками, а также с региональными альянсами, патронируемыми Соединенными Штатами.

Хотя Запад оказал широкую политическую поддержку властям Украины после переворота в стране в феврале 2014 г., набор практических мер помощи, которые он мог себе позволить, был сравнительно ограничен. Эти ограничения были связаны как с характером вызовов, перед которыми оказались власти Украины, так и с особенностями самой страны, делавшими затруднительным, а подчас невозможным оказание эффективного практического содействия.

По сравнению с другими клиентами Запада на постсоветском пространстве (наиболее очевидным примером может служить Грузия), Украина является крупным государством, обладающим значительными ресурсами. С советских времен Украина унаследовала большие арсеналы различных видов вооружения, включая ракетное, а также военную промышленность. На протяжении многих лет Украина была экспортером вооружения и военной техники и сама оказывала помощь своим более слабым постсоветским партнерам. Так, она продавала различные вооружения, в том числе средства ПВО, в Грузию накануне войны августа 2008 г.

И по количеству, и по качеству вооружений Украина превосходила Донецкую и Луганскую народные республики, хотя ее потенциал мог быть и был дополнительно усилен за счет поставок так называемых нелетальных средств со стороны США и их союзников. В то же время преодолеть отставание Украины в военной сфере от России, которую в Киеве считают главным источником угрозы, можно было только за счет очень масштабной и дорогостоящей помощи. США и их союзники не были готовы оказывать такую помощь. Отметим, что и Грузия в минувшем десятилетии пользовалась содействием США и НАТО в подготовке своих вооруженных сил, однако проводила перевооружение армии за счет средств собственного бюджета.

Одной из крупнейших проблем Украины остаются высокий уровень коррупции и низкое качество государственного управления. Это является препятствием для предоставления стране значительной материальной помощи, поскольку доноры не могут быть уверены, что выделенные ими средства будут потрачены в соответствии с оговоренными целями. Те сравнительно скромные объемы помощи, которые получала Украина в последние годы, выделялись при определенных условиях, в том числе касавшихся политических назначений. Они не станут для Украины источником быстрого экономического роста, за счет которого в перспективе она могла бы нарастить свой оборонный потенциал.

С учетом этого содействие Украине в военной сфере выразилось преимущественно в укреплении ее связей с НАТО, в помощи в подготовке ее вооруженных сил и расширении практики совместных учений. Поставки на Украину вооружений пока носят эпизодический характер.

С 2014 г. НАТО сделал Украину одной из центральных тем повестки в ходе двух встреч на высшем уровне и оказал тем самым Киеву широкую политическую поддержку. Декларация саммита НАТО в Уэльсе (сентябрь 2014 г.) включала упоминания «агрессии России против Украины» и «аннексии Крыма», требовала от России «вывести войска», в том числе и с российских территорий, прилегающих к Украине, возлагала на Москву ответственность за деэскалацию на востоке Украины. Наряду с этим было принято решение о повышении оперативной совместимости вооруженных сил Украины и НАТО². Заявление по итогам Варшавского саммита НАТО (июль 2016 г.) воспроизвело эти оценки, наряду с призывами к исполнению Минских соглаше-

\footnotetext{
${ }^{1}$ Венгрия заблокировала заседание комиссии Украина - НАТО // Интерфакс. 2018. 9 февраля. - URL: http://www.interfax. $\mathrm{ru} /$ world/599306

2 Заявление по итогам встречи на высшем уровне в Уэльсе // Официальный сайт HATO, 5 ceнтября 2014. - URL: https:// www.nato.int/cps/en/natohq/official_texts_112964.htm?selectedLocale $=$ ru
} 
ний по урегулированию кризиса на востоке Украине, причем основная ответственность за это, вопреки соответствующим документам, возлагалась на Россию³.

Практическая поддержка Украине со стороны НАТО выразилась в создании четырех целевых фондов (позднее их число было увеличено до шести). Общий бюджет фондов был определен в 15 млн евро ${ }^{2}$. Решение об их создании было принято в ходе саммита НАТО в Уэльсе в сентябре 2014 г. Правда, к концу года сообщалось, что удалось собрать только 4,5 млн евро5. Предоставленные НАТО суммы оказались многократно ниже, чем помощь Украине со стороны США.

Целевые фонды, созданные для содействия Украине, были ориентированы на реформирование украинских ВС в направлении их большей совместимости с НАТО, улучшения их управления и логистики, защиты от киберугроз, укрепления военной медицины, а также направлены на профессиональную переподготовку бывших военных по гражданским специальностям ${ }^{6}$. Сотрудничество с Украиной по линии этих фондов не включало в себя собственно боевую подготовку украинских военных или обеспечение их оружием: НАТО не стремилось открыто оказывать помощь киевским властям в гражданской войне в Донбассе. По некоторым направлениям помощь была заведомо минимальной; так, ведущей страной по целевому фонду защиты от киберугроз стала Румыния, очевидно не являющаяся технологическими лидером в данной сфере.

Хотя события 2014 г. НАТО признал исключительным вызовом безопасности Украины и самого альянса, они не заставили Брюссель качественно активизировать практическое содействие Киеву. Как ни парадоксально, наиболее важными для властей Украины в их противостоянии Донбассу были те программы сотрудничества с НАТО, которые были начаты до 2014 г. Так, с 2012 г. была начата программа укрепления военного образования на Украине, крупнейшая из программ такого рода с государствами - партнерами НАТО. В ее рамках поддержку получили восемь военных учебных заведений (в Киеве, Львове, Харькове, Одессе, Житомире) и пять тренировочных центров для сержантского состава (в Десне, Яворове, Старичах, Николаеве, Василькове). Эта программа позволяет политическому руководству Украины ускоренно заменять в вооруженных силах офицеров, получивших образование в советских или российских военных учебных заведениях, новыми кадрами, ориентированными на конфронтацию с Россией и сближение с Западом. С 2006 г. идет обмен данными с НАТО о ситуации в воздушном пространстве Украины, он был расширен после 2014 г. ${ }^{7}$ Подчеркнем, что в институциональном плане не потребовалось существенного изменения порядка взаимодействия НАТО с Украиной для реагирования на кризис, возникший в 2014 г. Комиссия Украина - НАТО, программы помощи Украине, действовавшие ранее, оказались в целом с точки зрения альянса достаточными для ответа на новый вызов. Брюссель направил больше ресурсов на это направление, не меняя его структурные характеристики.

Из этого следует, что ключевые механизмы сотрудничества Украины и НАТО были созданы в тот период, когда взаимоотношения России и НАТО не носили остро конфронтационного характера, однако не потребовали качественных изменений в ситуации, когда конфронтация резко усилилась. Механизмы вовлечения Украины в структуры безопасности, связанные с НАТО, которые были созданы в условиях низкого уровня конфронтации между альянсом и Россией, оказались пригодными для ситуации гораздо более острого противостояния. По сути, НАТО и Украина оказались институционально готовы к тому политическому курсу, который был ими взят в 2014 г.

\section{Поставки военного снаряжения и оружия на Украину}

Украинская пресса, ссылаясь на данные министерства обороны страны, оценила зарубежную помощь военными материалами, которая была оказана Украине с января 2014 г. по июль

\footnotetext{
3 Заявление по итогам встречи на высшем уровне в Варшаве // Официальный сайт HATO, 9 июля 2016 г. - URL: https:// www.nato.int/cps/en/natohq/official_texts_133169.htm?selectedLocale=ru

${ }^{4}$ Страны НАТО поставят Украине высокоточное оружие // Коммерсант. 2014. 4 сентября. - URL: https://www.kommersant. $\mathrm{ru} / \mathrm{doc} / 2559915$

${ }_{5}^{5}$ Украина приготовилась вступать // Коммерсант. 2014. 24 декабря. - URL: https://www.kommersant.ru/doc/2639643

${ }^{6}$ Поддержка, оказываемая НАТО Украине // Официальный сайт НАTO, июль 2016. - URL: https://www.nato.int/nato_ static_fl2014/assets/pdf/pdf_2016_07/20160627_1607-factsheet-nato-ukraine-support-rus.pdf

${ }^{7}$ Relations with Ukraine // Официальный сайт НАTO, March 9, 2018. - URL: https://www.nato.int/cps/en/natohq/topics_37750. htm?selectedLocale $=$ en
} 
2016 г. 18 государств, большинство из которых - члены НАТО, поставили Украине снаряжения на сумму более 164 млн долл., причем на первом месте по объему поставок оказались США (не учитывались расходы США по другим направлениям помощи Украине). Украина получила системы имитации тактических действий MILES, используемые для подготовки военнослужащих, радиостанции, устройства ночного видения, бронежилеты, радары контрбатарейной борьбы. Радиостанции, устройства для разминирования, бронежилеты и другое снаряжение поставляла и Канада, она оказалась на втором месте после США по объему помощи. Снаряжение направляли также Польша и Великобритания ${ }^{8}$. США поставили Украине также 100 военных автомобилей Humveе ${ }^{9}$ и беспилотные летательные аппараты ${ }^{10}$. По данным издания «Новое время», государства НАТО в общей сложности передали вооруженным силам Украины более 200 автомобилей повышенной проходимости, почти 6 тыс. приборов ночного видения и тепловизоров, более 4 тыс. средств связи, более 5 тыс. кевларовых шлемов и бронежилетов, почти 30 тыс. аптечек, 300 тыс. сухих пайков ${ }^{11}$. При этом Пентагон опубликовал материалы, согласно которым к концу ноября 2015 г. США оказали Украине военную помощь на 265 млн долл., включая сюда поставки снаряжения и расходы на подготовку украинских военнослужащих силами американских инструкторов ${ }^{12}$. Военный бюджет США на 2018 г. предполагает выделение Украине помощи еще на 350 млн долл. ${ }^{13}$ Министерство обороны Украины сообщило, что помощь оказал также Китай. Он поставил Украине оборудование для офтальмологической клиники на сумму 3,4 млн долл. ${ }^{14}$

Поставлялось Украине и оружие. Такие поставки осуществляли бывшие республики СССР и бывшие государства - члены Варшавского договора, утилизировавшие собственные запасы вооружений. Так, в 2016 г. сообщалось, что Литва передала Украине 150 тонн боеприпасов, которые хранились на ее территории с советских времен ${ }^{15}$. Также она передала Киеву 146 крупнокалиберных пулеметов советских образцов, взамен купив аналогичные пулеметы бельгийского производства ${ }^{16}$. Ранее, в начале 2015 г., министр обороны Литвы заявил, что та передала Украине «элементы вооружения», не раскрывая, о чем именно шла речь ${ }^{17}$. В августе 2014 г. одно из венгерских изданий опубликовало материал, согласно которому правительство через посредников поставляет Украине танки Т-72 и другую бронетехнику; МИД России объявил это нарушением обязательств Венгрии по контролю над экспортом обычных вооружений ${ }^{18}$.

До конца 2017 г. в поставках оружия на Украину не принимали участие США и другие «старые» члены НАТО. Но в декабре 2017 г. администрация президента Д. Трампа одобрила поставку Украине снайперских винтовок М107A1 ${ }^{19}$. Несколькими днями ранее Канада внесла Украи-

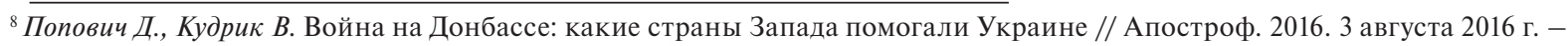
URL: https://apostrophe.ua/article/politics/2016-08-03/voyna-na-donbasse-kakie-stranyi-zapada-pomogali-ukraine/6566.

${ }^{9} 100$ военных «Хаммеров» из США прибыли в Одессу - Пайетт // УНИАН. 2015. 18 июля. - URL: https://www.unian.net/ politics/1102281-100-voennyih-hammerov-iz-ssha-pribyili-v-odessu-payett.html

${ }^{10}$ US Sends More Security Equipment to Ukraine, Sanctions Rebels // Defence News, March 11, 2015. - URL: https://www. defensenews.com/global/europe/2015/03/11/us-sends-more-security-equipment-to-ukraine-sanctions-rebels/

${ }^{11}$ Как Украина сотрудничает с НАTO. Инфографика // Новое время. 2017. 16 июля. - URL: https://nv.ua/ukraine/events/ kak-ukraina-sotrudnichaet-s-nato-infografika-1477873.html

${ }^{12}$ Ferdinando L. U.S. Begins Second Phase of Ukrainian Training, Equipping Mission // US Department of Defense, November 23, 2015. - URL: https://www.defense.gov/News/Article/Article/631007/us-begins-second-phase-of-ukrainian-training-equippingmission/

${ }^{13}$ США согласовали выделение Украине \$ 350 млн на военные расходы // Коммерсант. 2017. 9 ноября. - URL: https://www. kommersant.ru/doc/3461426?

${ }^{14}$ Виступ речника Міністерства оборони України під час брифінгу в Українському кризовому медіа-центрі // Официальный сайт Министерства обороны Украины. 2016. 15 июля. - URL: http://www.mil.gov.ua/news/2016/07/15/vistup-rechnikaministerstva-oboroni-ukraini-pid-chas-brifingu-v-ukrainskomu-krizovomu-media-czentri--/

${ }^{15}$ Литва заявила про передачу Україні боєприпасів вперше за два роки // Deutsche Welle Украина. 2016. 3 сентября.

16 Литва поставила Украине 146 крупнокалиберных пулеметов // Укринформ. 2017. 28 января. - URL: https://www. ukrinform.ru/rubric-world/2165037-litva-postavila-ukraine-146-krupnokalibernyh-pulemetov

${ }^{17}$ Министр: Литва передала Украине элементы вооружения // DELFIю 2015. 5 января. - URL: https://ru.delfi.lt/news/ politics/ministr-litva-peredala-ukraine-elementy-vooruzheniya.d?id=66816314

${ }^{18}$ МИД РФ прокомментировал сообщение венгерских СМИ о поставке Киеву бронетехники // Интерфакс. 2014. 15 августа. - URL: http://www.interfax.ru/business/391632

${ }^{19}$ Trump administration approves lethal arms sales to Ukraine // The Washington Post, December 20, 2017. - URL: https:// www.washingtonpost.com/news/josh-rogin/wp/2017/12/20/trump-administration-approves-lethal-arms-sales-to-kraine/?utm term $=.213 \mathrm{fd} 6 \mathrm{a} 110 \mathrm{ef}$
} 
ну в список стран, которым канадские компании могут продавать летальное оружие ${ }^{20}$. Наконец, в феврале 2018 г. Госдепартамент США одобрил продажу Украине противотанковых ракетных комплексов Javelin (210 ракет, 37 пусковых установок); сумма контракта, включающего также обучение украинских военнослужащих, составляет 47 млн долл. ${ }^{21}$ Украинские политики на протяжении нескольких лет требовали от США поставки современных противотанковых систем, рассматривая такие системы как важный элемент военного сдерживания Донецкой и Луганской народных республик, а также как инструмент противостояния с Россией. Президент Украины П. Порошенко в 2015 г. заявил, что Украина должна получить 1240 ПТРК Javelin - по числу ядерных боеголовок, которые находились на территории Украины в момент распада СССР и от которых Украина отказалась в соответствии с Будапештским меморандумом 1994 г. ${ }^{22}$ По-видимому, украинские власти и публика переоценивают значение ПТРК Javelin для соотношения сил на Донбассе. Поставки отдельных современных видов оружия не могут создать общего перевеса вооруженных сил Украины над их противником в гражданской войне. Тем более невозможно за счет этих поставок обеспечить паритет с Россией. Военный бюджет Украины растет, однако этот рост не может компенсировать отставание от России, особенно в свете масштабного перевооружения российских ВС, проведенного в последние годы. Военная промышленность, оставшаяся Украине в наследство от Советского Союза, в настоящее время в значительной степени разрушена и не может обеспечить страну современными видами вооружения. Как показала история приобретения ПТРК, Украина нуждается в импорте вооружений; при этом импорт дороже продукции национального производства, что может встретить политические препятствия и не оказывает позитивный эффект на национальную экономику.

В то же время поставки вооружений из наиболее развитых в военно-техническом отношении стран НАТО стали важным прецедентом, поскольку состоялись несмотря на многочисленные предупреждения (в том числе публичное заявление президента) со стороны России. Запад не демонстрирует желания вооружать Украину в той мере, которая необходима последней, чтобы создать зримую угрозу России. Однако политическое ограничение на поставки современных летальных вооружений на Украину, действовавшее с начала кризиса, к концу 2017 г. было фактически снято.

По некоторым признакам можно судить, что США стремятся избежать ситуации, когда современные противотанковые вооружения, поставленные на Украину, применялись бы в зоне конфликта на востоке страны. Как заявил замминистра Украины по вопросам временно оккупированных территорий и внутренне перемещенных лиц Георгий Тука, по требованию Соединенных Штатов комплексы Javelin не могут размещаться и использоваться на линии соприкосновения ${ }^{23}$. Это может быть связано как с опасностью возможного захвата комплексов вооруженными силами Донецкой и Луганской народных республик, так и со стремлением не дать России повода для ответных действий.

Североатлантический альянс и входящие в него страны, несмотря на политическую поддержку, которую они оказывают Украине, к настоящему моменту не готовы подкрепить эту поддержку значительной материальной помощью. При нынешнем уровне их содействия Украине в военно-технической сфере, страна не может преодолеть своего отставания от России. В то же время это содействие они, по-видимому, расценивают как достаточное, чтобы поддерживать баланс между ВСУ и силами ДНР и ЛНР в Донбассе.

\section{Участие Украины в военных учениях со странами НАTO}

Как и общая повестка сотрудничества Украины с НАТО, практика ее совместных военных учений с государствами блока возникла задолго до кризиса 2014 г. Военно-морские учения Sea Breeze проводятся Украиной и СШАс 1997 г. С 2011 г. проводились учения Rapid Trident. Taкже

\footnotetext{
${ }^{20}$ Иванова А. «Очень опасный прецедент»: Канада одобрила поставки оружия Украине // Russia Today. 2017. 14 декабря. URL: https://russian.rt.com/ussr/article/459918-kanada-voennaya-pomosch-ukraina

${ }^{21}$ Ukraine - Javelin Missiles and Command Launch Units // Defense Security Cooperation Agency, March 01, 2018. - URL: http:// www.dsca.mil/major-arms-sales/ukraine-javelin-missiles-and-command-launch-units

22 «Убийцы танков» прибудут в Украину. Что следует знать о мощных комплексах Javelin // TCH. 2018.18 января. - URL: https://ru.tsn.ua/ukrayina/ubiycy-tankov-pribudut-v-ukrainu-chto-sleduet-znat-o-moschnyh-kompleksah-javelin-1089295.html

${ }^{23}$ Георгій Тука: В мене складається стійке враження, що росіяни в черговий раз розпочали торгівлю полоненими // Прямий. 2018. 4 мая. - URL: https://prm.ua/137542/
} 
Украина проводила учения со своими соседями - членами НАТО. С 1999 г. проводятся учения «Кленовая арка» («Кленова арка»), в которых участвуют наряду с Украиной Польша, Литва и Канада ${ }^{24}$. В дальнейшем они стали учениями совместного польско-литовско-украинского батальона. С 2002 г. инженерные войска Украины, Венгрии, Словакии и Румынии проводят учения «Светлая лавина» («Світла лавина») по ликвидации последствий стихийных бедствий в Карпатах; с этой целью в 2002 г. был создан совместный батальон «Тиса». Совместно с Польшей проводились учения ВВС «Безопасное небо» («Безпечне небо»).

Интенсивность совместных учений со странами НАТО была относительно невелика в период президентства В. Януковича. Она стала увеличиваться, начиная с 2014 г., хотя в этом году боевые действия в Донбассе заставили перенести сроки проведения некоторых учений. При этом Украина стала активнее участвовать в тех учениях НАТО, в которых она ранее не участвовала, что стало наиболее зримым свидетельством укрепления сотрудничества между Украиной и альянсом.

С помощью информационно-аналитической системы «Семантический архив» был составлен перечень международных военных учений, в которых принимала участие Украина с 2014 по 2017 гг. Всего состоялось 55 таких учений, причем интенсивность их возрастала. Если в 2014 г. было запланировано участие Украины в 8 международных учениях с участием стран НАТО, то в 2017 г. - в 20. Помимо уже проводившихся ранее учений, были запущены новые. Так, в 2015 г. прошли учения Fearless Guardian, в которых приняли участие подразделения Национальной гвардии Украины. Как и учения Rapid Trident, которые прошли в этом же году, они были ориентированы на отработку навыков, которые требовались ВСУ и Нацгвардии в ходе боевых действий в Донбассе ${ }^{25}$. Увеличился масштаб учений: если в 2014 г. в учениях Sea Breeze приняли участие 2,5 тыс. человек и 15 кораблей и судов обеспечения, то в 2016 г. -4 тыс. человек и 25 кораблей.

Украина стала принимать участие в учениях НАТО в странах Восточной Европы. В июне 2016 г. она приняла участие в крупнейших учениях НАТО в регионе Anaconda (31 тыс. участников), с 2016 г. регулярно принимает участие в учениях вооруженных сил государств Прибалтики Flaming Sword u Flaming Thunder. Она также отправляет свои подразделения на крупные учения Saber Guardian, которые в 2017 г. проходили в Румынии и число участников которых достигло 25 тыс. человек. Украинские военнослужащие участвуют также в учениях американских сил в Европе: весной 2017 г. они присоединились к учениям Saber Junction, которые прошли в Германии на полигоне Хохенфельс. Они также участвовали в крупнейших за много лет маневрах НАТО в Средиземном море и Атлантике Trident Juncture, которые состоялись в октябре-ноябре 2015 г. и в которые были вовлечены все государства альянса и ряд его партнеров, 140 самолетов и вертолетов, 60 кораблей, катеров, судов обеспечения, 36 тыс. военнослужащих. Обращает на себя внимание, что по численности войск, принимающих участие в международных учениях, в которых задействована также Украина, с большим отрывом лидируют США. Можно с уверенностью сказать, что именно они несут на себе основную тяжесть поддержки Украины и осуществления политики сдерживания в отношении Москвы.

Интенсивность и характер совместных военных учений Украины и стран НАТО таковы, что в течение нескольких лет Украина значительно повысит совместимость своих вооруженных сил с вооруженными силами альянса. Само по себе это не обеспечит Киеву ни гарантированную победу в гражданской войне на востоке Украины, ни военный паритет с Россией. Однако сделает Украину для НАТО более удобным партнером, в том числе и в плане использования ее территории для возможных действий против России. Кроме того, из офицерского состава ВСУ будут практически вытеснены кадры, получившие военное образование в России и ориентированные на неконфронтационный курс в ее отношении. Военная организация Украины в определяющей мере окажется под влиянием Североатлантического альянса.

Участие американских военнослужащих в международных учениях, проходящих под эгидой НАТО и государств - членов и партнеров альянса, стало способом обеспечить правовую рамку для постоянного присутствия военнослужащих этих государств на территории Украины. В 2016 и 2017 гг. указом президента Украины им предоставлялось право находиться на терри-

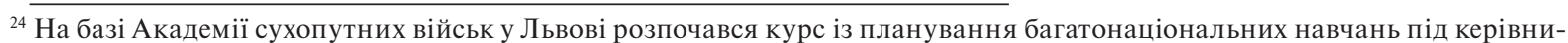
цтвом канадських та українських інструкторів // Официальный сайт Министерства обороны Украины. 2013. 30 октября. - URL: http://www.mil.gov.ua/news/2013/10/30/na-bazi-akademii-suhoputnih-vijsk-u-lvovi-rozpochavsya-kurs-iz-planuvannyabagatonaczionalnih-navchan-pid-kerivnicztvom-kanadskih-ta-ukrainskih-instruktoriv/

${ }^{25}$ Rapid Trident - 2015: учения в условиях гибридной войны // Deutsche Welle. Украина. 2015. 21 июля.
} 
тории страны в течение всего года, причем численность американского воинского контингента могла составить 1,5-3 тыс. человек с вооружением и военной техникой ${ }^{26}$. Это позволяет сделать постоянным обучение военнослужащих ВСУ американскими инструкторами, а также обеспечивает постоянное присутствие американских войск на территории Украины. Не имея военных баз на территории Украины, по крайней мере, формально, США поддерживают свое военное присутствие в этой стране, причем в большем масштабе, чем на территориях ряда стран соседей Украины и членов НАТО. Впрочем, и здесь есть место определенной осторожности: американские военнослужащие размещаются на Западе страны, на удалении от зоны конфликта в Донбассе и вдалеке от российской границы.

\section{Украина и «дияемма союза»}

В отношениях НАТО и США с Украиной в полной мере проявляет себя явление, в литературе получившее название «дилеммы союза»: союзник должен предоставить гарантии безопасности достаточные, чтобы партнер был в них уверен, но при этом избежать своего вовлечения в нежелательную для него войну [8]. В действенности гарантий также должно быть уверено и государство, которое по замыслу своих участников должен уравновешивать союз. Если обязательства по союзу ненадежны, то тот, кто предоставляет гарантии, теряет свою репутацию, а тот, кто получает гарантии, не может обеспечить свою безопасность за счет союза и предпочитает отказываться от него. Если обязательства, наоборот, слишком велики, то тот, кто их предоставляет, рискует оказаться в ситуации, когда не сможет избежать вовлечения в войну. В свою очередь государство, против которого направлен союз, может превентивно отреагировать на наращивание гарантий безопасности в рамках этого союза.

Расширение НАТО привело к своеобразной инфляции обязательств. Подобно тому как накануне финансового кризиса 2007-2008 гг. в США участники рынка не замечали, что гарантии по ценным бумагам становились всё более эфемерными, так и Вашингтон наращивал свои обязательства перед государствами Восточной Европы, не рассчитывая, что международная среда в регионе однажды станет гораздо жестче, чем это было в 1990-х или в первой половине 2000-х гг. Вместе с тем способность Соединенных Штатов защитить своих союзников - это один из столпов их статуса как единственной сверхдержавы и мирового гегемона. Поэтому украинский кризис породил калейдоскопическую пестроту стратегий США в отношении партнеров внутри и вне НАТО, поэтому итоговые документы саммитов НАТО всё более многословны, детализированы и неконкретны. С одной стороны, гарантии, данные в спокойные времена, требуют подтверждения, как это происходит с Прибалтикой и Польшей. С другой стороны, подтверждая обязательства перед партнерами, важно не быть чрезмерно вызывающими в отношении России.

Иллюстрацией к «дилемме союза» может быть и Украина. Обещанное Киеву членство в НАТО не может быть ему предоставлено в тех условиях, которые сложились с 2014 г. Но и сохранять отношения с Украиной на прежнем уровне, не говоря уже о сокращении неформальных гарантий, Вашингтон не может: в его глазах это означало бы сдачу позиций перед лицом России. Украину нельзя назвать первоклассным союзником. Формально являясь одним из крупнейших европейских государств, она может быть лишь в ограниченной степени защищать себя и многократно уступает России по ключевым показателям мощи. Тем сложнее задача США и их партнеров по НАТО: Киев (и Москву) нужно заверить в решимости Североатлантического альянса содействовать обеспечению безопасности его партнера, но это содействие не должно привести на грань прямого столкновения с Россией.

Отсюда и то, что внешнему наблюдателю может показаться колебаниями Вашингтона и Брюсселя. Помощь по линии НАТО Украине оказывается, но в незначительных объемах. Летальное вооружение предоставляется, но до недавнего времени лишь со стороны второстепенных членов НАТО. Современное противотанковое оружие Украина получила на условиях

\footnotetext{
${ }^{26}$ План проведення багатонаціональних навчань за участю підрозділів Збройних Сил України на території У країни та їх участі у багатонаціональних навчаннях поза межами України на 2016 рік // Официальный сайт президента Украины. 2015. 24 декабря. - URL: http://www.president.gov.ua/storage/j-files-storage/00/15/81/ca40cbf5a0449dc9e6647e65e4ddda2f_145 1142000.pdf; План проведення багатонаціональних навчань за участю підрозділів Збройних Сил України на території України та їх участі у багатонаціональних навчаннях поза межами України на 2017 рік // Официальный сайт президента Украины. 2017. 12 января. - URL: http://www.president.gov.ua/documents/32017-21122
} 
покупки, его поставка, по имеющимся сведениям, оговорена условиями, которые призваны минимизировать негативную реакцию России. Американские войска постоянно присутствуют на украинской территории, однако лишь у западной границы страны.

Примечательно, однако, то, что усилия Соединенных Штатов по тонкой балансировке отношений с Киевом не оценили и не могут оценить в Москве. В этой «дилемме союза» Россия играет роль того «третьего», против кого направлен союз и кого он призван сдерживать, не провоцируя. И можно с уверенностью судить, что любые шаги США и НАТО по оказанию помощи Украине в Москве будут считать лишь очередной попыткой втянуть соседнюю страну в НАТО и оказать давление на Россию. Союзнические или квазисоюзнические, как у Украины с США, отношения не всегда оказываются благом. Иногда они связывают своим участникам руки, одновременно обманывая их ложными надеждами.

\title{
АИТЕРАТУРА
}

1. Данилов Д. А. Стратегия национальной безопасности Украины: возможные последствия для российско-украинских отношений // Современная Европа. - 2016. - № 2. - С. 33-37.

2. Колтон T., Чapan C. Победителей нет: украинский кризис и разрушительная борьба за постсоветскую Евразию // Россия в глобальной политике. Специальный выпуск. - 2017. -184 с.

3. Курылев К. П. Внешняя политика Украины в контексте формирования региональной системы безопасности в Европе. - М.: Изд-во РУДН, 2014.

4. Сушенцов A. А. Как в море корабли. Россия и Украина: отказ от взаимной зависимости // Россия в глобальной политике. - 2016. - № 2. - С. 54-67.

5. McFaul M. Moscow's Choice // Foreign Affairs. - Vol. 93, No. 6 (November/December 2014). - P. 167-171.

6. Mearsheimer J. J. Why the Ukraine Crisis Is the West's Fault // Foreign Affairs. - Vol. 93. No. 5 (September/October 2014). - P. 1-12.

7. Mearsheimer J. J. Defining a New Security Architecture for Europe that Brings Russia in from the Cold // Military Review. - 2016. May-June. - P. 27-31.

8. Snyder G. H. Alliance Politics. - Ithaca, N.Y.: Cornell University Press, 1997.

9. Yarhi-Milo, Keren; Lanoszka, Alexander; Cooper, Zack. To Arm or to Ally? The Patron's Dilemma and the Strategic Logic of Arms Transfers and Alliance // International Security. - Vol. 41. No. 2 (Fall 2016). - P. 90-139.

\section{NATO's aid for Ukraine after Maidan}

\author{
Nikolal Silaev, Ph.D. (history), senior researcher, \\ Center for the Caucasian studies and regional security, \\ Institute for International Studies MGIMO-University. \\ E-mail: nikolai.silaev@gmail.com
}

Summary. NATO - Ukraine relations for recent decades have been one of the key issues of the discussion on European security. Coup d'etat and the outbreak of civil war in 2014 have established new situation in these relations. Both sides have got boost for cooperation though new obstacles have appeared for their rapprochement. Analyzing the aid NATO and its principal members provide Ukraine one may consider what is the relations between NATO and Ukraine and what are the motives defining the proper form of aid. Despite broad political support for Ukraine NATO members are rather moderate in the field of practical aid. Arms supply is restrained. The dominating form of aid appears to be intensified joint military exercises and NATO's military presence of Ukrainian territory. Though US and other NATO members reaffirm and enhance their unformal commitments and guaranties to Ukraine they also try to avoid steps that could lead to direct confrontation with Russia. Thus NATO - Ukraine relations may illustrate "alliance dilemma".

Keywords: Ukraine, NATO, international aid, military cooperation, RussianUkrainian relations, alliance. 


\section{REFERENCES}

Colton T., Charap S. Pobeditelej net: ukrainskij krizis i razrushitel'naya bor'ba za postsovetskuyu Evraziyu [Everyone Loses: The Ukraine Crisis and the Ruinous Contest for Post-Soviet Eurasia]. Rossiya v global'noj politike. 2017. Special issue.

Danilov D. A. Strategiya nacional'noj bezopasnosti Ukrainy: vozmozhnye posledstviya dlya rossijsko-ukrainskih otnoshenij [Ukraine's National Security Strategy: Possible Implications for Russian-Ukrainian Relations]. Sovremennaya Evropa. - No. 2. March/April 2016. - P. 33-37.

Kurylev K. P. Vneshnyaya politika Ukrainy v kontekste formirovaniya regional'noj sistemy bezopasnosti v Evrope [Ukraine's Foreign Policy in the Context of the Formation of a Regional Security System in Europe]. Moscow: Izdatel'stvo RUDN, 2014.

McFaul M. Moscow's Choice. Foreign Affairs. Vol 93. No. 6 (November/December 2014). P. 167-171.

Mearsheimer J. J. Why the Ukraine Crisis Is the West's Fault. Foreign Affairs. Vol. 93. No. 5 (September/October 2014). P. $1-12$.

Mearsheimer J. J. Defining a New Security Architecture for Europe that Brings Russia in from the Cold. Military Review. May-June 2016. P. 27-31.

Snyder G. H. Alliance Politics. Ithaca, N. Y.: Cornell University Press, 1997.

Sushentsov A. A. Kak v more korabli. Rossiya i Ukraina: otkaz ot vzaimnoj zavisimosti [As in the sea ships. Russia and Ukraine: Refusal from Mutual Dependence]. Rossiya v global'noj politike. 2016. Vol. 14. No. 2. P. 54-67.

Yarhi-Milo, Keren; Lanoszka, Alexander; Cooper, Zack. To Arm or to Ally? The Patron's Dilemma and the Strategic Logic of Arms Transfers and Alliances. International Security. Vol. 41. No. 2 (Fall 2016). P. 90-139. 